\title{
Separating wheat and chaff: age-specific staffing strategies and innovative performance at the firm level
}

\author{
Katharina Frosch • Christian Göbel · Thomas Zwick
}

Accepted: 29 July 2011 / Published online: 8 September 2011

(C) Institut für Arbeitsmarkt- und Berufsforschung 2011

\begin{abstract}
Adopting a dynamic perspective, this paper investigates age-related staffing patterns in German establishments and their effect on innovative performance. First, we investigate how establishments achieve the necessary workforce rejuvenation-from the inflow of younger or from outflows of older workers. In addition, we explore whether certain staffing patterns are more likely to appear under different economic regimes. In a second step, we analyze whether an establishment's innovative performance is related to the staffing patterns it experiences. The analysis of linked-employer-employee data shows that most of the 585 German establishments covered rejuvenate by inflows of younger workers. Half of the establishments also use the outflow of older workers. Furthermore, workforces are more likely to become more age-heterogeneous in growing establishments. Finally, we do not find evidence that a youthcentered human resource strategy (always) fosters innovation.
\end{abstract}

\section{Den Weizen von der Spreu trennen - Altersbezogene Personalpolitik und Innovationen auf der Betriebsebene}

K. Frosch (凶)

Ludwig-Maximilians-University, Munich

and Max-Planck-Institute for Demographic Research, Rostock, Germany

e-mail: frosch@bwl.lmu.de

C. Göbel

Centre for European Economic Research (ZEW), Mannheim,

Germany

e-mail: goebel@zew.de

T. Zwick

Ludwig-Maximilians University, Munich and Centre for European Economic Research, Mannheim, Germany

e-mail: zwick@bwl.lmu.de
Zusammenfassung Dieser Beitrag untersucht die altersbezogene Personalpolitik deutscher Betriebe und deren Einfluss auf die Innovationsfähigkeit. Zuerst wird dargestellt, wie Betriebe verhindern, dass ihre Belegschaften altern. Beispielsweise werden bevorzugt jüngere Beschäftigte eingestellt und ältere Beschäftigte verlassen den Betrieb. Anschließend wird geprüft, ob bestimmte Einstellungs- und Entlassungsstrategien stärker in bestimmten wirtschaftlichen Umständen erfolgen. In einem zweiten Schritt wird analysiert, ob die Innovationsleistung von Betrieben mit deren Personalpolitik zusammenhängt. Die Analyse von verknüpften Beschäftigten-Betriebsdaten zeigt, dass die Mehrheit der untersuchten Betriebe sich durch das Einstellen jüngerer Beschäftigte verjüngt. Die Hälfte dieser Betriebe entlassen zudem Beschäftigte, die älter als der Durchschnitt der Belegschaft sind. Wir finden zudem, dass sich die Altersheterogenität in wachsenden Betrieben erhoht. Schließlich finden wir keine Evidenz dafür, dass eine jugendzentrierte Personalpolitik die Innovationsfähigkeit der Betriebe verbessert.

\section{Introduction}

The lack of skilled labor is seen as a major threat to the innovative capacity of highly developed economies. Particularly in emerging technological fields, companies desperately hunt for workers who can simultaneously draw upon up-to-date specialist knowledge and substantial work experience, who are geographically mobile and understand different cultures and ways of thinking, and who can deal easily with both technical and business issues. In most cases, such highly sought-after jacks-of-all-trades are assumed to be young. At the same time, firms fear the loss of valuable 
expertise, with large cohorts of long-tenured and well educated baby boomer workers approaching retirement.

Meanwhile, from an empirical perspective, we know little about the age-dependency of innovative capacity. Previously, mostly cross-sectional evidence at the individual level, as well as at the aggregate level of firms pointed toward decreases in innovative capacity at older ages. However, a major problem is the omission of unobserved factors that drive innovation, and which are, at the same time, related to age (e.g., education, occupation or the characteristics of the firm a worker is employed). For this reason, the use of cross-sectional data implies the risk of erroneous estimation results for the age-innovation pattern. In most cases, the contribution of older workers to innovative performance tends to suffer from a systematic downwards bias. This may be because they work in firms with older technological equipment, or in occupations and industries that are beyond the peak-innovation stage in the technology cycle; or because, on average, older workers tend to have lower educational attainment.

If the contribution of different age groups at the aggregate level of firms is assessed, reverse causation is an additional source of estimation bias: if age-specific worker flows are related to the performance of the firm or region, a firm's age structure is not only a determinant of its performance; it is, at the same time, also its product. If, for example, younger and highly mobile workers select themselves into highly productive and innovative firms, while older workers tend to remain in less prolific firms, the performance estimates for older workers are further downwardly biased.

Indeed, longitudinal studies on age effects on general productivity at the firm level show that older workers fare much better than the age-performance pattern found in individual-level studies suggests if potential omitted variables and reverse causation are controlled for by standard econometric tools (e.g., Malmberg et al. 2008; Göbel and Zwick 2009). However, due to the very limited availability of data on age and innovation, such longitudinal evidence is not yet available for the age dependency of innovation.

Despite the lack of conclusive evidence on the age pattern in innovative capacity, with ongoing demographic changes, firms fear looming shortages of young professionals and busts in their innovative capacity when their incumbent workforces age (Verworn and Hipp 2009). They therefore seek to shape their staffing strategy with respect to the recruitment, retention and laying off of workers to prevent such losses. This study therefore aims to investigate to what extent the staffing strategies currently favored by firmscentered on the engagement of young and highly skilled workers and the retention of highly skilled and long-tenured workers-really leads to an improved innovative performance. ${ }^{1}$

Therefore this study intends to explore the effect of the necessary rejuvenation-different age characteristics of workers' in- and outflows to a company-on its innovative performance. In contrast to previous studies on age effects in innovation that mainly adopt a static perspective, we identify patterns with respect to the hiring, retention and separation of workers of different age and tenure levels for German firms. Germany is an excellent showcase for such a study. On the one hand, the competitiveness of the German economy strongly draws upon innovative capacity. On the other hand, in the coming two decades, Germany will experience considerable workforce aging, resulting in increases of up to 15 percentage points in the share of 50- to 64-year-olds in the employed workforce, especially if employment rates among the older population improve.

In recognition of the fact that rigidities external to the firm, such as shortages of (young) highly skilled professionals on the labor market or legal restrictions, hinder firms from fully controlling their workforce composition, we suggest interpreting empirically traceable, prevailing staffing patterns on the labor market as potential strategic regimes that German firms could, theoretically, adopt, even at the present time. In times of demographic change, there seems to be considerable agreement among business decision makers that adopting a strategy of rejuvenation of the workforce, whereas retaining long-tenured workers with valuable firmspecific experience, is the best option for coping with the potential negative effects of demographic change on innovation. Therefore, our focus is on quantifying the comparative advantage of firms with promising labor turnover and retention patterns with respect to innovative performance.

This study is based on a linked employer-employee dataset for Germany. Innovation is measured by a concise metric indicator-i.e., the share of new products or services in turnover-for the years 2000 and 2003, and covering several hundred plants. We investigate three issues. First, which staffing patterns with respect to older and younger workers currently prevail in German firms? Second, which firms are most likely to pursue the preferred staffing pattern that is directed toward rejuvenation through hiring younger and separating from older workers? Third, how is a firm's innovative performance related to the staffing pattern? In other words, to what extent does separating the wheat from the chaff based on demographic criteria actually affect innovative performance?

\footnotetext{
${ }^{1}$ There are a number of studies on the productivity effects of HR practices, such as Huselid (1995) or Datta et al. (2005). Moreover, a recent study by Zhou and Dekker (2010) focuses on the impact of labor relations on innovative performance in Dutch firms. However, to our knowledge, none of the existing studies focuses on staffing patterns, i.e., the in- and outflow of workers.
} 
The rest of the chapter is organized as follows. Section 2 provides an overview of concepts and previous empirical evidence on the staffing patterns firms experience in the current demographic and labor market situation and with respect to specific age groups. Section 3 presents the empirical approach to shed light on the research questions raised above. Results are presented and discussed in Sect. 4. Section 5 concludes with a summary and some directions for future research.

\section{The age dimension in firms' staffing decisions}

\subsection{Firms' age-related staffing strategies}

Firms' staffing strategies consist of the recruitment and retention of, and the separation from, workers with specific skills and characteristics, as well as their efficient allocation to the available jobs (e.g., Miller 1984; Sonnenfeld and Peiperl 1988; Koch and McGrath 1996). Companies hire new people or lay off workers in order to increase or reduce their workforces. Beyond engagements and separations prompted by new job creation or job destruction, firms also replace workers in existing jobs, either to respond to workerinduced fluctuation, or to replace workers they have laid off for whatever reason. In this context, Burgess et al. (2000a, p. 886) state that 'any given level of employment growth [or cutbacks] can be achieved by different combinations of hires and separations', and that 'this level of churning ${ }^{2}$ is the connection between worker flows and job flows.'

Generally, we would assume that firms try to hire and retain workers who boost innovative performance, and to separate from less prolific employees (Huselid 1995, p. 635). Labor turnover can then lead to increased innovative performance through an improved average innovative capacity. However, attempts to change the skill mix of their workforce by churning workers only work if the gains in performance do at least compensate for the adjustment costs induced by labor turnover (Abowd and Kramarz 2003). Shedding light on these firm-driven dimensions of labor turnover therefore involves identifying individual factors that are relevant for innovative performance.

First, innovative capacity is known to be strongly related to knowledge and expertise. Apart from variations in innovative capacity according to educational achievement, we would expect newly hired and incumbent workers with a

\footnotetext{
${ }^{2}$ Churning is defined as worker flows beyond new job creation and job destruction, i.e., turnover that only leads to the replacement of employees by external hires in existing jobs, and does not occur in order to cope with employment growth or decline (Burgess et al. 2000b, p. 477; Boockmann and Hagen 2002, p. 385; Boockmann and Zwick 2004, p. 53).
}

long tenure to systematically differ in their capacity to innovate, even if they have the same educational attainment. On the one hand, newly hired workers lack firm-specific experience, and need intensive on-the job training, whereas longtenured workers can draw upon extensive firm-specific experience (Becker 1962), and are well-matched to their current position (Jovanovic 1979). In this context, Daniel and Heywood (2007) have presented cross-sectional evidence that firms with long internal training periods before a new worker reaches the same productivity as an experienced worker, hire fewer older workers. Therefore, firms may be making a mistake when they dismiss older workers with valuable tacit experience. Moreover, the disruption of informal communication structures may be a concern, especially in the case of outflows of long-tenured workers.

On the other hand, recently hired workers with a short tenure may be better skilled in bridging structural knowledge holes toward new networks and emerging knowledge fields outside the company (Gabbay and Zuckerman 1998). This latter aspect indicates that labor turnover may be conducive to innovation, even if it involves an exchange of workers with a similar individual capacity for innovation. However, high churning levels may lead to operational disruption if key professionals or central 'nodes' of the internal communication structure get lost (Staw 1980, p. 256).

Leaving aside the assumptions that older workers have more expertise, and that the newly hired workers with the greatest ability to bridge structural knowledge holes are mostly younger, the literature has pointed out further variations in the innovative capacity across age, mainly related to further aspects touching upon the portfolio of human capital. Over the life course of workers, human capital is prone to obsolescence (De Grip and Van Loo 2002), particularly specialist knowledge acquired in formal education completed in early adulthood, and when working in domains subject to fast technological change (Vandenbussche et al. 2006). Continuously updating one's stock of human capital over the course of a career can partly offset obsolescence, but the incidence of life-long learning has been found to be far lower for older than for younger workers (OECD 2007b; Leuven and Oosterbeek 1999 p. 324; Skirbekk 2004, p. 136; Asplund 2005). Furthermore, only younger cohorts have had the chance to obtain education in emerging fields, such as IT starting in the 1980s, or biotechnology starting in the 1990s.

A large body of literature, for example, has pointed out age-related declines in cognitive abilities that have been found to be relevant in the creation of novel achievements, e.g., divergent thinking abilities (Schaie 1958; Reese et al. 2001). Meanwhile, verbal and social skills important for 'interunit resource exchange and product innovation, the creation of intellectual capital and cross-functional team effectiveness' (Adler and Kwon 2002, p. 17) tend to remain constant over the life course (Autor et al. 2003; Daveri and 
Maliranta 2007; Skirbekk 2008). Finally, the fact that older workers are increasingly affected by health impairments (Ilmarinen 2006, pp. 158-171), or may suffer from decreased work motivation (Kanfer and Ackerman 2000, 2004; Sturman 2003, p. 613), can reduce their innovative capacity, as the knowledge and expertise they have are not fully brought to bear.

Based on the assumption that there are productivity differentials not only between younger and older workers, but also between newly hired, incumbent and exiting workers, two recent studies have focused on the productivity effects of age-specific flows of labor from and into the firm, i.e., the hiring and dismissal or voluntary departures of younger, prime-aged and older workers, respectively. Relating gross value added in several thousand Finnish firms over a time period of eight years to the in- and outflows of workers of different ages, Ilmakunnas and Maliranta (2007) showed that dismissals of older workers (age 49+) with potentially outdated skills enhance productivity, whereas separations from prime-aged workers hamper a firm's productivity, and that these effects are particularly high in innovative industries, such as ICT. Surprisingly, in none of the estimation models referring to the ICT industry hiring younger workers was found to enhance productivity.

In a similar study for Finnish firms, Maliranta et al. (2009) go beyond age-specific staffing patterns, and additionally differentiate between the previous and the new occupational position of hires, as well as the tenure and educational levels of hires, leavers and stayers. Their focus is on inter-firm knowledge spill-over in R\&D. As expected, based on our previous conceptual considerations, the results suggest that the separation from highly educated workers may hamper productivity, whereas the engagement of younger workers may increase productivity. However, after looking at the results in more detail, we find that simply resuming the hiring of younger workers does not boost productivity. Instead, we find that only hiring younger workers who are also highly skilled actually improves productivity. Similarly, separating from older workers is only conducive to firm productivity if they do not belong to key performing groups, i.e., the highly skilled or the R\&D workforce. Interestingly, however, the transfer of younger and older hires from $R \& D$ departments in one firm to non-R\&D occupations at another firm is shown to boost productivity. Several interpretations are possible as to why the obsolescence of innovation-relevant human capital does not seem to play a major role for this specific type of inter-firm worker flow. On the one hand, firms may only poach similarly prolific workers, regardless of their age. On the other hand, the ability to make use of previous work experience in an R\&D department in a new, perhaps more managerial function may be the main driver of performance.

However, whereas the first study at least controls for time-constant, unobserved heterogeneity by accounting for firm fixed effects through the use of differences-in-variables instead of levels, the second one is purely of a crosssectional nature. Furthermore, in both studies, the endogeneity of the age structure is a concern ${ }^{3}$ : If strongly performing firms attract new and mainly younger workers, the positive effect of hires in this age segment may result from reverse causation, rather than from age-related productivity differentials, and because these studies look at many workforce subgroups, instrumental variable approaches cannot be applied (Maliranta et al. 2009, p. 30). ${ }^{4}$ Finally, general productivity in firms operating in the ICT industry is affected by many factors other than the innovative capacity of the workforce. Taking gross value added as a performance indicator therefore only partially meets our goal of explaining innovative performance.

Apart from these methodological issues, it is apparent that simply linking a firm's decision to hire, retain or separate from a worker to the assumed productivity of this worker is taking a view that is too narrow: if increases in a certain subgroup of workers boost innovative performance, this could also result from the fact that the company has moved to a workforce composition that is more favorable overall with respect to innovation. This asks to what extent workers with different characteristics complement each other with their specific portfolios of knowledge, skills and expertise, above and beyond their direct contribution to innovative firm performance. Apart from implementing new products and services, employees may also more tacitly contribute to innovations by enhancing the performance of other workers, e.g., by taking over managerial tasks, or through knowledge exchange and transfer (Meyer 2010). If we assume such complementarities ${ }^{5}$ between age groups, it can make sense for firms to employ workers who are scarce in their current workforce, even if the individual capacity for performance of this segment of workers is lower than that of the best-performing segment. A certain level of age diversity may therefore be conducive to innovative performance. Indeed, based on their study of linked employer-employee data of several thousand German firms from 1993 to 2001, Veen and Backes-Gellner (2009) found that the more agediverse a firm's workforce is, the higher its productivity in

\footnotetext{
${ }^{3}$ Ilmakunnas and Maliranta (2007) apply an instrumental variable approach, but only on the total sample and not in the ICT sector which is more relevant when looking on age effects in innovation than less knowledge intensive sectors.

${ }^{4}$ The authors mention, for example, that the application of instrumental variables to cope with potential endogeneity of age-specific hiring and separations is only possible if the number of worker characteristics controlled for is limited.

${ }^{5}$ For similar reasons, Prskawetz and Fent (2007), as well as Guest (2007), for example, strongly recommend applying formal models that are based on the assumption of imperfect substitutability (or: complementarity) between workers of different ages.
} 
knowledge intensive industries. In contrast to this result, age-heterogeneity is found to be detrimental with respect to productivity in more traditional industries. ${ }^{6}$

In conclusion, labor turnover is useful for firms that are filling newly created positions or reducing their workforces to separate from under-performers or to replace underperformers by highly innovative new workers with a high level of education, relevant work experience and the capacity to bridge structural knowledge holes. Furthermore, more age-heterogeneous workforces may foster innovative performance. Labor turnover is dysfunctional, however, if firm-specific expertise or key performers are lost, or if turnover moves the firm toward a less favorable workforce composition - or, more generally, if the costs of labor turnover exceed its benefits.

\subsection{Strategic staffing patterns, employment growth and dominant firms}

Up to now, we have assumed that firms are completely free in implementing their preferred staffing strategy. However, this is not realistic. Labor turnover comes in very different guises. Engagements and separations in, for example, certain age groups (Hamermesh et al. 1996, p. 25) do not unequivocally reveal to what extent these workers' flows are the result of firms' deliberate staffing decisions, or whether they are driven by workers' preferences, legal restrictions or social acceptance, as well as by the availability of skilled workers on the labor market (Burgess and Nickel 1990; Burgess et al. 2000b). For example, outflows not only consist of planned layoffs by firms, but also of voluntary quits. In particular, the most productive and innovative workers have most opportunities for job-to-job changes (Allen and Griffeth 1999), and the costs associated with changing jobs may be outweighed by gains in earnings for this group. Moreover, worker characteristics, such as age that firms take as signals for a high capacity of innovation, are not necessarily a guarantee that a recruit or a retained worker will display an above-average performance, as there are performance differentials within each target segment of workers. Productivity differences between workers of the same age group have even been consistently found to be more pronounced than between workers of different ages (Warr 1993, p. 238). In conclusion, firms can neither fully control the age, education and tenure mix of the workforce nor the churning level ${ }^{7}$; and

\footnotetext{
${ }^{6}$ This latter result is also in line with evidence provided by Düzgün (2008) and Börsch-Supan and Weiss (2008) who show that error rates increase with age-heterogeneity in work teams in a large German car manufacturing plant.

${ }^{7}$ Note that estimating the average contribution of turnover in different subgroups of workers, e.g., skilled younger hires or older long-tenured leavers, to firm performance, as in Ilmakunnas and Maliranta (2007) and Maliranta et al. (2009), implicitly draws upon this assumption.
}

even if they could, they would not necessarily be able to hire and retain the most prolific workers for innovation.

However, in this chapter we argue that evidence on the effects of different staffing patterns on innovative performance can nevertheless shed light on the question of which staffing strategies firms would be theoretically able to implement given the current labor market situation, and which staffing strategy would be most favorable for innovation-if firms could completely control labor turnover. In the context of aging workforces and innovation, we look at different kinds of labor turnover inducing changes in the workforce. The following staffing patterns may be conducive to innovation:

- Rejuvenation, i.e., whether and to what extent a firm's workforce does not grow older on average by one year from year to year.

- Workforce age diversification, i.e., whether a firm's workforce becomes more age-heterogeneous over time.

- A certain churning level may intensify the exploration of new knowledge fields, but this comes at the price of the disruption of grown communication and cooperation structures.

These three dimensions can result from very different combinations of age-specific fluctuations and engagements (Burgess et al. 2000a, p. 886). Rejuvenation can, for example, be caused either by the engagement of younger workers or by the voluntary or involuntary separation from older workers, or of both phenomena at the same time. Similarly, the age diversity of a firm's workforce increases if dismissals or voluntary departures are in age groups that are highly represented, or if newly hired workers are of an age that is not that well represented in the firm's current workforce age structure.

Closely connected to this, we suggest that the firms' staffing patterns strongly vary according to whether the firms experience workforce growth or decline. An expanding firm will, for example, prefers to rejuvenate their workforce by hiring additional young workers, whereas a firm in a period of downsizing either allows its workforce to grow older, or, if it chooses to rejuvenate, it can achieve this by ensuring that leavers are older than the average age of employees (Daniel and Heywood 2007). Additionally, not only the staffing pattern itself, but also its effect on innovative performance should vary depending on whether a firm experiences a period of employment growth or decline: losing older workers with experience in coping with economic downturn and organizational upheaval caused by cut-offs in employment may, for example, be more detrimental than losing younger workers, even if they have high levels of up-to-date specialist knowledge. In periods of employment growth, the inflow of these young professionals may be crucial for innovative performance. 
Finally, as mentioned above, workers who are less or more experienced, or who are young or old are not homogeneous with respect to unobservable characteristics, such as motivation, loyalty or creativity. In this context, and referring back to the theory of labor market segmentation (Doeringer and Piore 1971), we suggest that 'dominant ${ }^{8}$ firms with attractive internal labor markets and generous compensation and benefit systems are particularly able to attract employees from other firms, and to employ younger and to retain older, long-tenured workers in times of employment growth. If forced to reduce their workforce, they primarily lay off less skilled workers in all age groups, as well as older, short-tenured workers. Churning on average improves job match and productivity and the capacity for innovation. 'Dominated' firms with lower wage levels and less attractive career opportunities are not always able to attract the types of worker they would like to hire, especially when those workers are already employed by their rivals, and they therefore engage less skilled and older workers. ${ }^{9}$ In periods of workforce decline, they lose a considerable number of young, mobile workers, as well as highly skilled workers in all age groups and long-tenured older workers who move to take advantage of better options on the external labor market.

However, even if dominant firms are better able to implement staffing strategies identified as promising based on observable worker characteristics, such as age or tenuresimply implementing these strategies may or may not lead to increased innovative performance, as success strongly depends on a firm's ability to attract and retain the most motivated, loyal and creative workers within each segment, and to shed less prolific workers. With respect to the effect of staffing patterns on innovative performance among dominant versus dominated firms, two conflicting assumptions are possible. On the one hand, the above-described staffing patterns may have a more pronounced (positive) effect on innovative performance for dominant firms than for dominated firms, as they hire and retain the most prolific workers in each of the targeted groups. On the other hand, staffing patterns assumed to be more favorable to innovation may be of little relevance for dominant firms, as they would in

\footnotetext{
${ }^{8}$ This differentiation-albeit referring to the poaching of employees trained by other firms-draws upon Léné (2002), who refers back to earlier work by Cahuc et al. (1990) on labor market segmentation and wage determination. He describes dominant firms with wellfunctioning internal labor markets that are able to attract and retain workers with high levels of human capital. Dominated firms with less attractive career opportunities however lose valuable and self-trained workers to dominant firms.

${ }^{9}$ In this context, Daniel and Heywood (2007) found for British firms that deferred compensation and internal labor markets are a strong negative predictor for the hiring of older workers. Therefore dominant firms hire fewer older workers than dominated firms.
}

any case succeed in recruiting and retaining the most prolific workers, regardless of whether they are, for example, old or young.

In conclusion, we propose that the observable staffing patterns of German firms and their effects on innovative performance vary across growth and dominance regimes. However, even if dominant firms are more able to pursue staffing patterns favorable to innovation, the question of whether this drives innovation or if they anyway recruit and retain the most prolific workers in all target groups remains to be explored in the course of this study.

\section{Approach}

\subsection{Data}

The study draws upon a linked employer-employee dataset for Germany (LIAB) provided by the Research Data Centre of the German Federal Employment Agency at the Institute of Employment Research (IAB). With a representative annual sample of 4,000 to 16,000 German establishments between 1993 and 2008, and almost seven million workers, it combines administrative employment data from the social security statistics for almost all individual workers on June 30th of the respective year, with survey information about organizations they work for (for details see Jacobebbinghaus 2008). It should be noted that only organizations with at least one employee subject to social insurance are covered.

As we focus on innovative capacity, instead of on general productivity, we have chosen to restrict the analysis to the two most recent waves of the LIAB, whereby the plantlevel survey includes detailed questions on innovative performance, which are the years 2001 and 2004 that refer to innovative output in 1999/2000 and 2002/2003, respectively. As not all companies that innovate have provided reliable replies to the questions related to the share of turnover achieved by innovation, and/or workforce flows, indicators cannot be computed for some firms. If there is no workforce information for the preceding two years, as is the case, for example, for the newly founded establishments, the final dataset used consists of 585 observations, referring to 245 establishments in 2000 and 340 establishments in 2003, employing a total of more than 200,000 employees.

\subsection{Relating staffing patterns of German firms to innovation}

Firms' innovative performance is measured by the share of turnover achieved with new products and services developed in the last two years preceding the survey, see Wagner (2008), Criscuolo et al. (2010) or Verworn and Hipp (2009). 
To characterize the staffing patterns of firms, we compute different indicators based on changes in the firm's workforces over the two years prior to when innovative performance is observable, i.e., between $1998(t=1)$ and 1999 $(t=2)$ and between $2001(t=1)$ and $2002(t=2)$ for the innovation indicators in 1999/2000 and 2002/2003, respectively. Note that indicators related to the staffing patterns are based on full-time equivalents.

First, we assess whether firms' workforces are rejuvenated, and how they achieve this. If the share of young hires among all hires exceeds the share of young workers in the overall workforce, ${ }^{10}$ we qualify this as rejuvenating by hiring younger workers. Thus, new hires are identified as workers employed in year $t=2$ who have not been working in the establishment in $t=1$. Similarly, rejuvenation by separating from older workers applies if the share of older workers leaving the company of all separations exceeds the overall share of older workers in the establishment. Separations are identified as workers who have been working in the firm in $t=1$, and have left it by $t=2$. For these two indicators, the age groups for younger and older workers are set to younger than 35 years and 50 years or older, respectively. The two rejuvenation indicators can take any positive value. Values of one reveal that the workforce structure remains unaltered by the staffing strategy dimension in question. Values larger than one indicate that the firm rejuvenates, whereas values smaller than one indicate that the firm grows older by its hiring strategy.

Our second dimension of the staffing pattern is workforce age diversification analyzed on changes in the ageheterogeneity of firms' highly skilled workers. This is given by increases or decreases in the standard deviation of workers' age between $t=1$ and $t=2$ (Veen and Backes-Gellner 2009). Finally, the churning rate refers to firms simultaneously hiring and firing, and workers quitting and being replaced beyond what is needed to attain the level of employment growth or decline the firm experiences (Burgess et al. 2000a, p. 888; 2000b, pp. 477-479). We compute this rate according to Boockmann and Hagen (2002, p. 387), by setting the difference between the turnover rate ${ }^{11}$ and the net employment change in relation to the turnover rate.

Now, we still need to classify establishments according to their dominance regime. To differentiate dominant from dominated firms, we use the wage residual obtained from

\footnotetext{
${ }^{10}$ Hutchens (1986) and Daniel and Heywood (2007) use similar indicators for the hiring of older workers.

${ }^{11}$ The turnover rate $(T R)$ is the sum of the hiring rate $(H R)$ and the separation rate $(S R)$ between $t=1$ and $t=2$. Hiring and separation rates are computed as the numbers of hirings or separations, respectively, divided by the average workforce size across $t=1$ and $t=2$ (Davis and Haltiwanger 1999). The full formula for the churning rate is hence $C R=(H R+S R-\Delta E) /(H R+S R)$, with $\Delta E$ being the net employment change between $t=1$ and $t=2$.
}

running a pooled OLS wage regression at the firm level. ${ }^{12}$ Results are reported in Table A.3 of the Appendix. Firms that pay higher average wages to their workers as indicated by positive residuals are assumed to be able to pursue dominant strategies on the labor market. Dominated firms with negative residuals offer on average lower wages and potentially less attractive internal labor markets. Hereby we control for workforce and firm characteristics commonly assumed to affect wages. ${ }^{13}$

All aspects, including innovative performance, the hiring, separation and retention patterns, as well as the wage dynamics, are probably driven by overall trends in different industries, i.e., as the propensity to innovate differs, or as the whole industry declines due to structural changes in the economy. In order to eliminate this source of unobserved heterogeneity that may bias the results, the following analysis is based on deviations of the industry median ${ }^{14}$ of the respective indicator. We differentiate between (A) metal production and structuring; (B) mechanical engineering, vehicle manufacturing and shipping industry; $(\mathrm{C})$ electrical engineering and precision mechanics; (D) paper, textile and food; (E) building and construction and (F) other. The transformed indicators can be interpreted with reference to other firms in the same industry, i.e., a positive indicator value for the rejuvenation by hiring indicator reveals that the establishment experiences more rejuvenation by hiring young workers than the average establishment in the same industry.

Finally, expanding and downsizing firms are identified based on the change in employment in each of the two periods as percentage changes of the initial workforce size in the starting year of the period (growth regime). The growth indicator is not adjusted based on the median by industries, as we assume the staffing patterns to be directly affected by whether firms shrink or grow.

Relating the computed staffing indicators, as well as the information about the dominance and growth regime of an

\footnotetext{
${ }^{12}$ An alternative specification of dominance based on personnel measures such as high non-employer induced fluctuation in general, lack and loss of skilled labor, over-aged workforces as well as information about whether the respective establishment paid wages above the wages specified in collective agreement) did not yield different results.

${ }^{13}$ Workforce mean age and tenure (both in the linear and the quadratic terms, respectively), the shares of female, part-time and white-collar workers, firm size, investments, the condition of the technological infrastructure, the presence of a work council and the application of collective agreements, region and the year of the observation have been accounted for. Note that the inclusion of more detailed, categorical variables for workforce age groups or firm size neither changes the results nor improves the model fit.

${ }^{14}$ We also include small firms with only one or two employees. Therefore staffing pattern indicators can grow very large. In what follows, we therefore use the median instead of the mean for the adjustment by industry, and do not look at the absolute extent of a staffing pattern, but only at binary indicators, i.e. whether an establishment experiences a certain staffing pattern or not.
} 
establishment to its innovative performance, allows us to explore the prevalence of different staffing patterns in German firms, and the effects on their innovative output under different regimes of growth and dominance.

To the extent possible, systematic variance in additional determinants of innovative output that do not result from the staffing pattern should therefore be controlled for. In particular, other determinants of firms' innovative output that are also related to the staffing strategies and/or the growth and dominance regimes could cause-if they are not considered-an omitted variable bias. As additional determinants of firm-level innovative productivity, we therefore account for the following set of observable controls (Wagner 2008; Criscuolo et al. 2010): First, large firms are more likely to introduce or generate a new product than smaller firms, but if smaller firms do, the turnover share realized through innovations is higher than for their larger counterparts (Strotmann and Mathes 2005, p. 11). Firm size is accounted for by the average number of employees expressed in full-time equivalents for the respective establishment and year. Similarly, in some studies, firm age has been found to be negatively correlated to the probability to innovate in a study by Huergo and Jaumandreu (2004); however, other studies have found no effect (McGahan and Silverman 2001; Wagner 2008). We include firm age as a dummy variable that indicates whether the production equipment of the firm is in good technical condition (Göbel and Zwick 2009). Furthermore, investment activities aimed at enlargement and expansion per worker are accounted for.

The share of highly skilled workers, i.e., workers with a tertiary education degree, as well as mean age and mean tenure are considered. Additional workforce characteristics, such as the share of part-timers and the share of female workers are also taken into account. All workforce characteristics are computed based on full-time equivalents. Finally, establishments are categorized according to whether they are located in the former East Germany, and according to the six industrial sectors mentioned earlier.

It should be noted that the initial sample of more than 1,000 establishments with information on the turnover share achieved based on innovative products and services shrinks to 585 establishments. The largest part of the loss of observations results from the fact that, to construct the indicators based on workers flows, workforce information from the previous years is needed. This means that, for example, newly founded firms drop out of the sample. We should further note that the more specific our analysis, e.g., by looking at staffing patterns and dominance regimes, the more observations we lose due to increasing data needs. Finally, as only 27 establishments are covered in both years, the nature of the data does not allow us to use it by panel regressions in order to cope with potential omitted variable biases or reverse causation. Nevertheless, the robustness of the in-depth descriptive analysis provided in this study is thoroughly discussed and evaluated against alternative specifications.

\section{Results}

\subsection{Overview}

We start with some descriptive information about the establishments covered by the analysis (see also Table A.1 in the Appendix). Almost half of the companies employ between 50 and 999 workers, but four percent are very small establishments with one or two workers, and 10 percent are large companies with 1,000 workers or more. On average, and relative to the respective previous year, the establishments experienced employment growth of 7.5 percent. About 46 percent of the establishments are located in the former East Germany. The average workforce age in the establishments covered by the analysis is about 40 years and on average workers have already worked about seven years in the establishment they are employed at present.

Relative to a representative German establishment as provided in the full sample of the LIAB for the respective years, the establishments that provide usable information about their innovation activities are significantly larger, with an average of more than 300 full-time positions, compared with about 150 in the overall sample. These companies are also more likely to have a works council (61 versus 53 percent). Furthermore, almost 60 percent of the establishments covered in our study operate in the chemical, plastics and extraction industries or the metal production and structuring sectors, whereas this is only the case for about a onethird of the establishments in the full sample. With respect to the age structure, mean age and tenure, the location in eastern or western Germany, and the application of collective agreements, the companies in our sample do not significantly deviate from the full sample. However, on average, the workforces of the establishments covered in our study have significantly higher levels of educational attainment, have more age-heterogeneity, are less likely to be female or to work part-time, and are more likely to rate their technological equipment as being in excellent condition.

Classifying the establishments according to employment growth (Table 1) yields 308 growing firms with an average employment growth of 23 percent, and 277 downsizing firms with average employment reductions of 11 percent. With respect to dominance, 289 firms pay below-median wages relative to their counterparts in the same industry (dominated), whereas 296 firms pay at least average wages or higher, and are therefore classified as dominant. Detailed information with respect to the wage residuals used to compute the dominance indicator is available in Table A.3. Simultaneously looking at growth and dominance regimes 
Table 1 Innovative performance, dominance and growth

\begin{tabular}{|c|c|c|c|c|c|c|c|c|c|}
\hline \multirow{2}{*}{ Frequency distribution } & \multicolumn{2}{|l|}{$\Delta E \geq 0$} & & \multicolumn{3}{|c|}{$\Delta E<0$} & & \multicolumn{2}{|c|}{ Total } \\
\hline & $N$ & $(\%)$ & & $\bar{N}$ & & $(\%)$ & & $\bar{N}$ & $(\%)$ \\
\hline$D-($ dominated firms $)$ & 148 & 50.9 & & 141 & & 48.1 & & 289 & 49.4 \\
\hline$D+($ dominant firms $)$ & 160 & 49.1 & & 136 & & 51.9 & & 296 & 50.6 \\
\hline \multirow[t]{2}{*}{ Total } & 308 & 100 & & 277 & & 100 & & 585 & 100 \\
\hline & $\Delta E \geq 0$ & & $\Delta E<0$ & & $D+$ & & $D-$ & & All firms \\
\hline Innovation ( $\%$ of turnover) & 8.7 & & 8.2 & & 8.2 & & 8.8 & & 8.5 \\
\hline Employment growth (\%) & +23.3 & & -10.7 & & +1.6 & & +13.0 & & 7.5 \\
\hline$N$ & 308 & & 277 & & 296 & & 289 & & 585 \\
\hline
\end{tabular}

Notes: Pooled results for the years 2000 and 2003. Dominance determined based on industry-adjusted wage residuals based on the wage regression displayed in Table A.3. Source: Elaborated for this study based on LIAB data

leads to about a quarter of the observations in each of the four possible subgroups (dominant-growing, dominantdownsizing, dominated-growing, dominated-downsizing). Consequently, the dominance and growth regimes measure different phenomena-firms cutting their workforces are not necessarily dominated firms with less attractive internal labor markets or compensation packages.

As can be seen in Table 1 above and in Table A.2, on average, the establishments covered achieve 8.5 percent of their turnover with innovative products or services. For 75 percent of the establishments, the turnover share with innovative products does not exceed 10 percent, but the most innovative five percent of establishments yield turnover shares of between 30 and 95 percent. Furthermore, the difference in mean innovative performance between growing and declining, and between dominant and dominated firms, is not significant. ${ }^{15}$

\subsection{Strategic staffing patterns in German firms}

Table 2 presents the information used to compute the staffing patterns by different regimes of growth and dominance. For the sake of completeness, we also provide all indicators for the full sample of LIAB establishments, which shows that, with respect to workforce structure, workforce flows and staffing patterns, the average establishment in our innovation sample is rather similar to the average company in the full sample.

The upper part of the table focuses on the target groups in the total workforce, i.e., the share of younger workers (aged less than 35 years) and the share of older workers (aged

\footnotetext{
${ }^{15}$ Note that the information shown is based on raw and not industryadjusted indicators, The Wald test on the significance of group differences in mean values has been conducted based on the deviations of the respective industry median for each indicator in order to avoid that effects purely resulting from industry patterns confound the results.
}

50 years or older). The medium part of the table shows the corresponding target groups among worker inflows and outflows. Growing firms have a slightly younger workforce than downsizing firms, with 33 and 29 percent younger workers and 21 and 24 percent older workers, respectively. The differences between dominant and dominated firms in each growth regime are negligible.

Across all growth and dominance regimes, about half of newly hired workers or more are less than 35 years old, which indicates that, overall, firms rejuvenate by hiring younger - only about a third of the incumbent workforce consists of younger workers. However, growing firms experience a less pronounced influx of younger workers among all hires (five percentage points lower than their downsizing counterparts). Relating the share of young among the newly hired workers to the share of younger workers in the total workforce shows that overall, four out of five firms rejuvenate through hiring (lower part of Table 2). However, comparing dominant and dominated firms by employment growth reveals that 84 percent of dominant, growing establishments rejuvenate based on the influx of younger workers, whereas this in only the case for 69 percent of dominated, growing firms. One explanation for this pattern is that, in times of high labor demand and with the number of younger professionals becoming scarcer due to demographic change, dominated firms are less attractive employers and they therefore have to rely on other age groups to fulfill their labor demand.

Rejuvenation through the outflow of older workers is a less pronounced staffing pattern. Overall, only 42 percent of all establishments rejuvenate because their shares of older workers among all separations exceed the share of older workers in the total workforce. Moreover, the differences between the share of older workers among hires and among the total workforce are mostly marginal. The most striking exception are dominant-downsizing firms, in which the share of older workers among separations exceeds the share of 
Table 2 Workforce structure and flows by dominance and growth regime

\begin{tabular}{|c|c|c|c|c|c|c|c|c|c|c|}
\hline & \multirow{3}{*}{$\begin{array}{l}\text { All } \\
\text { total }\end{array}$} & \multicolumn{3}{|c|}{ Innovation sample } & \multicolumn{2}{|c|}{ Dominance } & \multicolumn{2}{|c|}{$\Delta E \geq 0$} & \multicolumn{2}{|c|}{$\Delta E<0$} \\
\hline & & \multirow[t]{2}{*}{ Total } & \multicolumn{2}{|l|}{ Growth } & \multirow[t]{2}{*}{$D+$} & \multirow[t]{2}{*}{$D-$} & \multirow[t]{2}{*}{$D+$} & \multirow[t]{2}{*}{$D-$} & \multirow{2}{*}{$D+$} & \multirow[t]{2}{*}{$D-$} \\
\hline & & & $\Delta E \geq 0$ & $\Delta E<0$ & & & & & & \\
\hline \multicolumn{11}{|l|}{ Target groups among workforce (\%) } \\
\hline Young & 31.9 & 31.5 & 33.3 & 29.4 & 31.4 & 31.5 & 33.0 & 33.7 & 29.6 & 29.2 \\
\hline Old & 23.4 & 22.4 & 20.9 & 24.0 & 22.1 & 22.7 & 20.5 & 21.3 & 23.9 & 24.2 \\
\hline \multicolumn{11}{|c|}{ Target groups among worker inflows and outflows (\%) } \\
\hline Young among inflow & 51.8 & 55.1 & 52.8 & 57.8 & 57.2 & 52.9 & 55.9 & 49.4 & 58.7 & 56.8 \\
\hline Older among outflow & 24.7 & 25.0 & 21.6 & 28.5 & 26.1 & 23.8 & 22.1 & 21.1 & 30.4 & 26.6 \\
\hline \multicolumn{11}{|l|}{ Other workforce flow indicators } \\
\hline Outflow rate (per 100 workers) & 7.9 & 7.9 & 8.7 & 7.0 & 6.7 & 9.0 & 6.9 & 10.6 & 6.6 & 7.3 \\
\hline Inflow rate (per 100 workers) & 7.9 & 7.5 & 10.8 & 3.8 & 6.4 & 8.6 & 8.7 & 13.6 & 3.8 & 3.8 \\
\hline Age-heterogeneity (years) & 9.3 & 10.0 & 10.0 & 10.1 & 9.9 & 10.2 & 9.6 & 10.3 & 10.1 & 10.1 \\
\hline \multicolumn{11}{|l|}{ Staffing patterns (on average, by group) } \\
\hline Rejuvenating-inflow of younger (\% yes) & 75.1 & 79.0 & 77.0 & 81.3 & 82.3 & 75.4 & 84.1 & 69.0 & 80.2 & 82.4 \\
\hline$N$ & 10036 & 472 & 248 & 224 & 248 & 224 & 132 & 116 & 116 & 108 \\
\hline Rejuvenating—outflow of older (\% yes) & 42.2 & 42.8 & 33.8 & 52.2 & 45.2 & 40.2 & 36.8 & 30.4 & 54.3 & 50.0 \\
\hline$N$ & 9658 & 470 & 240 & 230 & 241 & 229 & 125 & 115 & 116 & 114 \\
\hline Churning level (rate) & 0.46 & 0.55 & 0.56 & 0.54 & 0.55 & 0.55 & 0.58 & 0.54 & 0.52 & 0.56 \\
\hline$N$ & 11905 & 531 & 288 & 251 & 271 & 260 & 144 & 136 & 127 & 124 \\
\hline Change in age-heterogeneity $(\%)$ & 2.2 & +3.8 & +8.9 & -1.7 & +5.6 & +1.9 & +11.8 & +5.9 & -1.3 & -2.1 \\
\hline$N$ & 14665 & 572 & 295 & 277 & 289 & 283 & 153 & 142 & 136 & 141 \\
\hline
\end{tabular}

Notes: Pooled results for the years 1998/1999 and 2001/2002. $N=15,891$ for the full sample and $N=585$ for the innovation sample. Note that the variation in case numbers per strategy results from the fact that the staffing patterns draw upon workforce flows that cannot be computed in many cases, if, for example, an establishment is not observed in the respective precedent periods. Source: Elaborated for this study based on LIAB data

older employees in the total workforce by more than six percentage points.

As rejuvenation by hiring younger employees has been a particularly relevant staffing pattern for growing establishments, making the workforce younger by separating from older workers is particularly relevant for establishments that downsize their workforces: 52 percent of downsizing companies, compared to only 34 percent of growing firms, experience this staffing pattern. However, under workforce decline, dominant firms (54 percent) are more likely to rejuvenate by outflows of older workers than their dominated counterparts (50 percent).

Employment increases and decreases are mainly controlled by different levels of hiring rates (four hires per 100 workers in downsizing firms, relative to 11 in growing firms), with the variation of outflow rates, at seven and nine per 100 workers, being less pronounced. In times of workforce growth, inflow rates are about one-quarter higher than outflow rates, whereas in times of workforce decline, outflow rates are about double those of inflow rates in all dominance regimes. Across all growth regimes, dominant firms display lower outflow rates than dominated firms, which may be a first hint that they are more successful in the retention of their workers.

Age-heterogeneity, as measured by the standard deviation of worker's age in every establishment is around 10 for all growth and dominance regimes. As for changes in age-heterogeneity, particularly growing (+8.9 percent) and dominant $(+5.6$ percent $)$ firms experience on average strong increases in age-heterogeneity, with a maximum of up to 12 percent for dominant, growing firms. ${ }^{16}$ Whether the increases in age-heterogeneity result from increases in younger or older age groups remains an open issue, as the average establishment in Germany, and also in the subsample used in this study, both younger and older age groups display rather low shares relative to the prime-aged groups between 30 and 49 (see also Table A.1). The churning rate amounts to 0.55 , and the variation between the different

\footnotetext{
${ }^{16}$ Based on industry-adjusted results for this staffing pattern in table, however, only the differences in the change of age-heterogeneity across growth regimes prove statistically significant.
} 
Table 3 Strategic staffing patterns by dominance and growth regime

\begin{tabular}{|c|c|c|c|c|c|c|c|c|}
\hline \multirow[t]{2}{*}{ Staffing strategies (\% yes) } & \multicolumn{2}{|l|}{ Growth } & \multicolumn{2}{|c|}{ Dominance } & \multicolumn{2}{|c|}{$\Delta E \geq 0$} & \multicolumn{2}{|c|}{$\Delta E<0$} \\
\hline & $\Delta E \geq 0$ & $\Delta E<0$ & $D+$ & $D-$ & $D+$ & $D-$ & $D+$ & $D-$ \\
\hline Rejuvenation-inflow of younger & 47.6 & 54.5 & 56.5 & 44.6 & 54.5 & 39.7 & 58.6 & 50.0 \\
\hline \multirow[t]{2}{*}{$N$} & 248 & 224 & 248 & 224 & 132 & 116 & 116 & 108 \\
\hline & \multicolumn{2}{|c|}{$p=0.136$} & \multicolumn{2}{|c|}{$p=0.010^{* *}$} & \multicolumn{2}{|c|}{$p=0.019 * *$} & \multicolumn{2}{|c|}{$p=0.197$} \\
\hline Rejuvenation-outflow of older & 42.1 & 59.1 & 51.9 & 48.9 & 43.2 & 40.9 & 61.2 & 57.0 \\
\hline \multirow[t]{2}{*}{$N$} & 240 & 230 & 241 & 229 & 125 & 115 & 116 & 114 \\
\hline & \multicolumn{2}{|c|}{$p=0.000 * * *$} & \multicolumn{2}{|c|}{$p=0.522$} & \multicolumn{2}{|c|}{$p=0.716$} & \multicolumn{2}{|c|}{$p=0.520$} \\
\hline High churning level & 55.0 & 49.4 & 51.7 & 53.1 & 56.9 & 52.9 & 45.7 & 53.2 \\
\hline \multirow[t]{2}{*}{$N$} & 280 & 251 & 271 & 280 & 144 & 136 & 127 & 124 \\
\hline & \multicolumn{2}{|c|}{$p=0.198$} & \multicolumn{2}{|c|}{$p=0.744$} & \multicolumn{2}{|c|}{$p=0.503$} & \multicolumn{2}{|c|}{$p=0.233$} \\
\hline Increasing age-heterogeneity & 59.3 & 42.2 & 54.3 & 47.7 & 62.7 & 55.6 & 44.9 & 39.7 \\
\hline \multirow[t]{2}{*}{$N$} & 295 & 277 & 289 & 283 & 153 & 142 & 136 & 141 \\
\hline & \multicolumn{2}{|c|}{$p=0.000 * * *$} & \multicolumn{2}{|c|}{$p=0.114$} & \multicolumn{2}{|c|}{$p=0.215$} & \multicolumn{2}{|c|}{$p=0.389$} \\
\hline
\end{tabular}

Notes: Pooled results for the years 1998/1999 and 2001/2002. Prevalence of staffing patterns as indicated by values above the median of the respective of all establishments operating in the same industry (= yes), by dominance and growth regimes. The $p$-values in the other columns indicate whether the share of establishments experiencing the respective staffing strategy differs between the two compared groups. Source: Elaborated for this study based on LIAB data. Significance levels $* 10 \%$, ** 5\%,*** $1 \%$

regimes of growth and dominance is small, i.e., 0.52 to $0.58 .^{17}$

Up to now, we have only described the staffing patterns that the German establishments covered by our analysis have experienced in the years 1998/1999 and 2001/2002. To confirm that the differences in the staffing patterns as identified for different regimes of growth and dominance are actually statistically relevant, we have conducted significance tests on the share of establishments in each regime that experience the staffing pattern into question. However, unobserved heterogeneity, because, for example, general upwards or downwards trends in employment in different age groups lead to typical staffing patterns in different industries, may confound our results. To reduce potential biases that may arise from the fact that we did not control for such issues, we first compute indicators for the five staffing patterns as deviations from the median in the industry the establishment operates in, and only then differentiate between establishments that have the respective staffing pattern to a greater or lesser extent than the median establishment in the same industry.

Table 3 shows for each strategic staffing pattern within the different growth and dominance regimes the share of establishments that experience the respective staffing pattern equally or more strongly than the median establishment in the same sector. The between-regime differences of the averages of these shares per group are tested for statistical

\footnotetext{
${ }^{17}$ The results for the mean churning rate and the low variation are in line with earlier results by Boockmann and Hagen (2002, p. 391).
}

significance based on Wald tests, and the results are provided by means of the corresponding p-values. Generally, the results based on raw indicators without adjustments by the industry median from Table 2 are substantiated: growing establishments are slightly less likely to fill their open positions with high shares of younger workers relative to their downsizing counterparts in the same industry, but the result is not statistically significant ( $p=0.136)$. Moreover, 57 percent of dominant firms rejuvenate by hiring younger workers, whereas only 45 percent of their dominated counterparts do so $(p=0.01)$. However, the most striking result is that the great majority of dominant firms (55 percent) apparently manage to rejuvenate through the inflow of younger workers, even in times of employment growth and thus high labor demand, whereas this is much less the case for their dominated counterparts (40 percent). The difference is significant at the five-percent level.

In addition, 59 percent of downsizing establishments rejuvenate by separating from older workers, which is significantly more often than their growing counterparts in the same industry (42 percent, $p=0.000$ ). However, the difference between dominant and dominated firms with respect to rejuvenation by separating from older workers, as identified in Table 2 does not prove to be statistically significant after adjusting for the industry. Furthermore, among growing firms, increases in age-heterogeneity are, at 60 percent of the establishments, by far more likely than in downsizing firms (42 percent, $p=0.000$ ). However, even if the descriptive differences in the likelihood of increases in ageheterogeneity between dominant and dominated firms seem 
to be rather pronounced, none of them is statistically significant.

The reader may now argue that the emergence of certain staffing strategies could suffer from omitted variable bias, even if we have carefully evaluated based on industry-adjusted indicators whether the prevalence of the five staffing patterns varies across dominance and growth regimes. However, despite this strategy of dividing establishments into more homogeneous subgroups, the emergence of our staffing patterns could depend on additional factors, such as the size of the establishment, whether it is located in the former East Germany, or whether it has an older or a younger workforce. If, at the same time, these factors are related to whether an establishment is growing or declining, or whether it is able to act as a dominant employer on the labor market, the depicted differences in the emergence of a certain staffing pattern across dominance and growth regimes may be no more than a statistical artefact. We therefore check whether (i) the dominance and growth regime and (ii) the (industry-adjusted) staffing strategies vary across establishment size, location, the condition of the technological equipment and per-worker investments for expansions, as well as across additional workforce characteristics, such as average age, age-heterogeneity and average tenure, and the share of academic, female and part-time workers (see Table A.4).

Spurious correlations between the emergence of a certain staffing pattern in a certain growth or dominance regime are only of concern if there is a significant heterogeneity with respect to a confounding factor related to both the staffing pattern and the regime of growth and dominance. We thereby concentrate on the three staffing patterns that display significant differences across regimes, according to our results in Table 3. Indeed, the finding that larger establishments with older and longer-tenured workforces rejuvenate more often, both by the inflow of younger and the outflow of older workers, and, at the same time, are less represented among growing firms, provides an alternative explanation for why growing firms rejuvenate less often than downsizing firms, as found in Table 3. However, the finding that growing and dominant establishments rejuvenate far more frequently, based on the inflow of younger workers, than growing dominated establishments should not be the result of a spurious correlation, as the relevant confounding factors are unrelated to the dominance regime (see Table A.5).

\subsection{Is innovative performance related to age-specific staffing patterns?}

The second question in the context of this study is how innovative performance is related to the different staffing patterns. For example, is innovative performance positively related to rejuvenation by inflows of younger workers? We ex- pect that the interplay between staffing patterns and innovativeness varies across dominance and growth regime. In particular, we propose that dominant firms are in any case able to attract and retain the most motivated, loyal and creative workers within each segment, and to shed less prolific workers. It therefore does not matter whether the company experiences staffing dynamics that are considered favorable to innovation. An alternative proposition is that staffing patterns only have an effect on innovation for dominant firms, because dominated firms are left with less able and motivated workers even if they, for example, rejuvenate. To investigate these conflicting propositions, we relate innovative output to staffing patterns within dominance and growth regimes.

Splitting our sample of 585 establishments into the four dominance and growth regimes leads to very small samples sizes. Therefore, we suggest a more explorative approach than estimating regression models of innovative performance on the staffing strategies and the number of additional determinants of innovative performance. Table 4 illustrates differences in mean innovative performance, depending on whether an establishment experiences a certain staffing pattern or not, for all firms, and separately by growth and dominance regimes. Both of the indicators used for determining the staffing patterns and innovative performance are computed as deviations from the median of all companies in the same industry in order to increase the homogeneity of the sample.

On first view, across all staffing patterns, dominant firms under growth display considerable differentials in innovative performance depending on whether the establishment experiences a certain staffing pattern. For example, in times of workforce growth, the turnover share achieved with new products and services of establishments that rejuvenate by inflows of younger workers is, on average, 5.5 percentage points higher than that of the median firm in the respective industrial sector; whereas for firms without this staffing patterns, the difference from the median firm amounts only to 3.2 percentage points. For dominated firms, it works the other way round, i.e., industry-adjusted innovative performance is lower if the establishment rejuvenates based on inflows of younger workers. Another exemplary result is that increases in workforce age-heterogeneity are related to higher innovative performance in growing, dominant firms, whereas they are associated with lower innovative performance in downsizing, dominated establishment. Initially, dominant firms appear to profit more from favorable strategies than their dominated counterparts, a finding we attribute to the higher ability of dominant establishments to attract and retain the most motivated, loyal and creative workers within each targeted workforce group, and to shed less prolific workers. However, in no group of the firms considered differences in innovative performance are significant, 
Table 4 Innovative performance and different staffing patterns

\begin{tabular}{|c|c|c|c|c|c|c|c|c|c|}
\hline & \multirow[t]{2}{*}{ All firms } & \multicolumn{2}{|l|}{ Growth } & \multicolumn{2}{|c|}{ Dominance } & \multicolumn{2}{|c|}{$\Delta E \geq 0$} & \multicolumn{2}{|c|}{$\Delta E<0$} \\
\hline & & $\Delta E \geq 0$ & $\Delta E<0$ & $\overline{D+}$ & $D-$ & $D+$ & $D-$ & $D+$ & $D-$ \\
\hline \multicolumn{10}{|c|}{ Rejuvenation by inflows of younger } \\
\hline - yes & 3.3 & 4.1 & 2.8 & 3.7 & 3.0 & 5.5 & 1.7 & 1.7 & 1.8 \\
\hline- no & 3.0 & 3.7 & 2.1 & 2.7 & 3.1 & 3.2 & 4.1 & 2.4 & 4.1 \\
\hline Test on difference ( $p$ ) & 0.710 & 0.810 & 0.664 & 0.616 & 0.960 & 0.323 & 0.240 & 0.737 & 0.301 \\
\hline \multicolumn{10}{|c|}{ Rejuvenation by outflows of older } \\
\hline - yes & 2.4 & 2.2 & 2.5 & 2.8 & 1.9 & 2.8 & 1.5 & 2.8 & 2.2 \\
\hline- no & 3.2 & 3.9 & 2.1 & 3.2 & 3.1 & 4.2 & 3.6 & 1.8 & 2.4 \\
\hline Test on difference $(p)$ & 0.434 & 0.242 & 0.760 & 0.785 & 0.350 & 0.520 & 0.292 & 0.652 & 0.911 \\
\hline \multicolumn{10}{|c|}{ Increasing age-heterogeneity } \\
\hline - yes & 3.8 & 4.3 & 2.1 & 3.8 & 3.1 & 5.2 & 3.3 & 1.5 & 2.8 \\
\hline- no & 3.5 & 2.9 & 4.6 & 2.9 & 4.7 & 2.2 & 3.4 & 3.4 & 5.6 \\
\hline Test on difference (p) & 0.720 & 0.286 & 0.124 & 0.527 & 0.290 & 0.151 & 0.938 & 0.354 & 0.251 \\
\hline \multicolumn{10}{|l|}{ Churning } \\
\hline - yes & 2.6 & 3.4 & 1.8 & 2.5 & 2.9 & 3.5 & 3.2 & 1.1 & 2.5 \\
\hline- no & 3.9 & 4.3 & 3.6 & 4.3 & 3.6 & 5.1 & 3.4 & 3.5 & 3.8 \\
\hline Test on difference ( $p$ ) & 0.212 & 0.539 & 0.209 & 0.233 & 0.599 & 0.451 & 0.923 & 0.354 & 0.517 \\
\hline
\end{tabular}

Notes: Pooled results for the years 1999/2000 and 2002/2003. The indicator refers to the mean innovative performance (turnover achieved by new products and services, in percent of total turnover, as deviation from the respective industry median) within each subgroup characterized by whether establishments experience the respective staffing strategy or not, as well as dominance and growth regimes. The $p$-values (in italic) refer to a Wald-Test on the means within the growth and/or dominance regimes depending on whether an establishment experiences the respective staffing pattern or not. Source: Elaborated for this study based on LIAB data

Significance levels $* 10 \%, * * 5 \%, * * * 1 \%$

regardless of whether the establishment experiences a certain staffing pattern to a greater extent than other firms in the same subgroup and industry.

Several explanations are possible for this result. First, innovative performance simply may not be related to the staffing patterns that are the focus of this study, at least if potential systematic co-variation of innovative performance and staffing patterns in industrial sectors is controlled for. That this possibility cannot be simply dismissed is also underlined by the recent results by Verworn and Hipp (2009). They used an innovation indicator that is based on a survey question with the exact wording in our dataset, and did not find any age dependency of innovation. ${ }^{18}$ Why then should age-related staffing patterns affect innovation? Still, we should not forget that both our results and those by Verworn and Hipp (2009) are of a purely cross-sectional nature, and the results may be biased by omitted variables or reverse causation. However, as has been extensively discussed in the literature survey, the great majority of estimation biases inflate the contributions of younger workers, and reduce

\footnotetext{
${ }^{18}$ Similarly, Ilmakunnas and Maliranta (2007) and Maliranta et al. (2009) do not find that hiring younger employees boosts productivity in the ICT sector.
}

the contributions of older workers to firm performance. Furthermore, as in our case, none of the strategies is significantly related to innovative performance, not even the influx of younger workers, and the usual pattern of estimation biases are clearly not a problem here.

Second, insignificant effects may also appear because the interpersonal differences within the workforce groups targeted, i.e., young newcomers and older leavers, are larger than the between-group differences (Warr 1993). In this case, a rejuvenation strategy, for example, does not per se lead to higher innovative performance. Rather, the success of the strategy depends on the ability of the firm to attract the most able young workers and to get rid of older underperformers.

Data quality is a third reason why in our study an establishment's innovative performance may appear not to be related to the staffing pattern. All of the companies included in our sample are already more innovative than the average German firm, as we only look at firms with a positive turnover share achieved based on new products or services. Moreover, based on for example average educational attainment and the affiliation to certain industries, we expect a response bias for survey questions related to innovations that favor innovative firms. This reduces the variation of innovative performance in our sample. Furthermore, reproduc- 
ing the industry-adjusted staffing patterns in Table 3 for the full sample of 15,891 firms, and testing whether they are more likely to appear in the full sample or in the reduced innovation sample, shows that sample response biases are related to staffing patterns (see Table A.4). For example, establishments that provide information about their innovative performance rejuvenate significantly more frequently due to higher relative inflows of younger workers (56 versus 50 percent) and due to higher relative outflows of older workers (55 versus 50 percent) than the median establishment in the same sector in the full sample. Finally, it may be difficult for the survey respondent to make judgments about the exact share of turnover achieved based on innovation. This creates a considerable amount of unsystematic variance in our innovation indicator.

Fourth, we also verify whether the methodology applied to determine industry-adjusted indicators for innovative performance and the staffing patterns leads to these inconclusive results. For example, the accuracy of separation may not be high enough if classifying the establishments into groups according to whether they experience a certain staffing pattern depends on whether they display indicator values above or below the industry median. However, applying the 40th and the 60th percentiles as lower and upper cut-off points and leaving out the one-fifth of establishments with staffing indicators close to the median establishment in the same industry, does not change the results.

\section{Conclusions and future research}

This paper reveals that most of the 585 German establishments covered in this analysis rejuvenate their workforce through inflows of younger workers, and that half of them also do so through the outflow of older workers. In a second step, we account for the fact that staffing patterns may not only vary according to whether an establishment currently experiences employment growth or decline, but also according to whether it is a dominant or a dominated employer. In order to avoid the problem that general trends in the staffing patterns by industrial sectors have the potential to confound the results, industry-adjusted indicators are used. Our results show that only rejuvenation as well as changes in the age-heterogeneity of the workforce, vary across growth and dominance regimes. Workforces are, for example, more likely to become more age-heterogeneous in growing establishments.

Moreover, in times of workforce decline, rejuvenation is primarily caused by outflows of older workers, and this is occurring regardless of the dominance regime. Further subdividing establishments into each growth regime according to whether they are dominant or dominated employers finally reveals that this phenomenon only proves true for dominated establishments. In contrast, more dominant establishments rejuvenate through the inflow of younger workers even in times of high external labor demand. Extensive robustness checks reveal that at least this latter aspect does not result from a purely spurious correlation.

This directly leads us to the second issue raised in this study: not only does it appear that dominant firms may be better able to implement staffing strategies favorable to innovation-even if dominant and dominated firms experience the same staffing pattern identified as promising based on observable worker characteristics-but it seems that these staffing strategies may or may not lead to increased innovative performance. According to our results, the innovative performance is not significantly related to any of the staffing patterns. So, for example, innovation is not demonstrably fostered by either the inflow of young professionals, or by the retention of older, experienced workers, even though this has been cited as being particularly important in times of economic downturn and organizational upheaval.

Nevertheless, if the results could be confirmed based on improved data, how would we interpret the missing link between age-related staffing patterns and innovative performance? Up to now, related studies have not provided any evidence that, for example, the inflow of younger workers with up-to-date formal knowledge and the capacity to build a bridge toward knowledge fields and networks new to the firm boosts innovative output. Furthermore, we have pointed out that young and old workers are not homogeneous with respect to unobservable characteristics, such as motivation, loyalty or creativity. In the latter context, our results allow for the interpretation that dominant firms are better able to separate the wheat and from the chaff from a double perspective: not only that they are able to pursue staffing strategies that are potentially more conducive to innovative performance (e.g., rejuvenation), they also able to recruit and retain the most prolific workers among all segments of workers. If dominant firms are in any case succeeding in recruiting and retaining the most prolific workers, regardless of whether they are, for example old or young, staffing patterns related to rough demographic categories would not be of much relevance for innovative performance. In this context, existing evidence supports the idea that the interpersonal differences within a certain workforce subgroup, e.g., young newcomers, may be higher than the average performance differences between groups, e.g., younger and older workers. In this case, the focus on the most prolific workers, regardless of their age or tenure, should be the strategy of choice for firms seeking to boost innovative performance and cope with aging workforces.

Based on the results of this chapter, there are some implications for business management, labor market policy and for future research on the topic. First, practitioners and policy makers should be aware that, despite all the efforts made 
in recent research, our knowledge about the interplay between workforce age, age-related staffing patterns and innovative performance remains very limited, especially due to the methodological caveats most studies experience. In this context, research on workforce age and innovation is still severely hampered by the lack of comprehensive data. It is high time to call for the creation of a longitudinal dataset that includes reliable innovation indicators, such as patenting activity, detailed R\&D expenditure or other innovation activities; as well as information about workers, their qualifications and their previous careers. Combining existing linked employer-employee datasets with official and reliable patenting statistics as for example suggested by Wagner (2010) would, for example, provide the opportunity to study the career courses of workers and innovation processes on a methodologically and conceptually sound basis.

Acknowledgements We thank Inga Freund for useful comments. We are grateful to two anonymous referees for helpful comments and suggestions. We also thank the Research Data Centre (FDZ) of the Federal Employment Agency at the Institute for Employment Research for their support with the analysis of the data. Financial support by the German Research Foundation (DFG) under its priority programme "Age Differentiated Work Systems" (grant ZW172/1-2) is gratefully acknowledged. This paper uses the cross section version 1 of the linked employer-employee data set (LIAB), years 1993-2006. Data access was provided via on-site use at the Research Data Centre (FDZ) of the German Federal Employment Agency (BA) at the Institute for Employment Research (IAB) and afterwards via controlled data remote access at FDZ.

\section{Appendix}

Table A.1 Selected firm and workforce characteristics

\begin{tabular}{|c|c|c|c|c|c|c|}
\hline & Innovation (\%) & Full (\%) & \multicolumn{2}{|c|}{ Workforce age shares } & Innovation (\%) & Full $(\%)$ \\
\hline \multicolumn{7}{|l|}{ Workforce size category } \\
\hline - less than 3 workers & 4.1 & 15.2 & \multicolumn{2}{|c|}{ - less than 20 years } & 2.5 & 3.0 \\
\hline - 3 to 9 workers & 11.6 & 18.8 & \multicolumn{2}{|c|}{-20 to 24 year } & 7.1 & 7.9 \\
\hline - 10 to 49 workers & 27.4 & 27.8 & \multicolumn{2}{|c|}{-25 to 29 years } & 8.4 & 8.9 \\
\hline - 50 to 999 workers & 46.8 & 35.2 & \multicolumn{2}{|c|}{-30 to 34 years } & 13.8 & 12.8 \\
\hline - 1000 workers or more & 10.1 & 3.0 & \multirow{2}{*}{\multicolumn{2}{|c|}{$\begin{array}{l}-35 \text { to } 39 \text { years } \\
-40 \text { to } 44 \text { years }\end{array}$}} & 16.9 & 15.6 \\
\hline & & & & & 15.9 & 15.2 \\
\hline Sector ${ }^{A}$ & & & \multicolumn{2}{|c|}{ - 45 to 49 years } & 13.2 & 13.6 \\
\hline - A & 26.5 & 13.8 & \multicolumn{2}{|c|}{ - 50 to 54 years } & 10.8 & 11.2 \\
\hline$-\mathrm{B}$ & 34.5 & 21.1 & \multicolumn{2}{|c|}{ - 55 to 59 years } & 8.4 & 8.6 \\
\hline$-\mathrm{C}$ & 13.9 & 18.2 & \multicolumn{2}{|c|}{ - 60 years or older } & 3.1 & 3.3 \\
\hline - D & 10.6 & 16.2 & & & & \\
\hline$-\mathrm{E}$ & $\sim 11.0^{\mathrm{B}}$ & 12.2 & \multicolumn{2}{|c|}{ Other characteristics (Yes) } & & \\
\hline$-\mathrm{F}$ & $\leq 3.4^{\mathrm{B}}$ & 18.4 & \multirow{2}{*}{\multicolumn{2}{|c|}{$\begin{array}{l}\text { - Work council? } \\
\text { - Collective agreement? }\end{array}$}} & 60.5 & 53.5 \\
\hline & & & & & 60.0 & 59.8 \\
\hline Year & & & \multicolumn{2}{|c|}{ - Good technical equipment? } & 76.2 & 66.3 \\
\hline-2000 & 41.9 & 38.8 & \multirow{2}{*}{\multicolumn{2}{|c|}{ - East Germany? }} & 46.0 & 46.3 \\
\hline \multirow[t]{3}{*}{-2003} & 58.1 & 61.2 & & & & \\
\hline & & \multicolumn{2}{|c|}{ Innovation sample } & \multicolumn{2}{|c|}{ Full sample } & Difference $^{\mathrm{C}}$ ? \\
\hline & & Mean & St. dev. & Mean & St. dev. & \\
\hline \multicolumn{2}{|l|}{ Workforce size (workers) } & 367 & 976 & 154 & 681 & $p=0.000$ \\
\hline \multicolumn{2}{|c|}{ Employment growth (\% of previous year) } & 7.5 & 131.1 & 11.4 & 228.5 & $p=0.696$ \\
\hline \multicolumn{2}{|c|}{ Mean age (years) } & 40.2 & 4.3 & 4.2 & 6.1 & $p=0.923$ \\
\hline \multicolumn{2}{|l|}{ Age-heterogeneity (years) } & 10.1 & 2.5 & 9.3 & 3.8 & $p=0.000$ \\
\hline \multicolumn{2}{|c|}{ Mean tenure (years) } & 7.0 & 4.2 & 7.0 & 4.5 & $p=0.965$ \\
\hline \multicolumn{2}{|c|}{ Academic (share in $\%$ of workforce) } & 12.7 & 17.7 & 8.2 & 16.0 & $p=0.000$ \\
\hline \multicolumn{2}{|c|}{ Female (share in $\%$ of workforce) } & 35.7 & 25.4 & 43.5 & 33.3 & $p=0.000$ \\
\hline \multicolumn{2}{|c|}{ Part-time (share in $\%$ of workforce) } & 11.0 & 28.0 & 22.1 & 79.6 & $p=0.001$ \\
\hline
\end{tabular}

Notes: Pooled results for the years 1999 and 2003, total $N=585$ for the sample of establishments that provides information about innovation activities and $N=15,891$ for the full sample

a (A) chemical, plastics and extraction (B) metal production and structuring, (C) mechanical engineering, vehicle manufacturing and shipping industry, (D) electrical engineering and precision mechanics, (E) paper, textile and food (F) other

${ }^{b}$ Due to confidentiality issues for the social security data, the exact values cannot be displayed

${ }^{c}$ Results of a Wald test on the difference between mean values in the full sample as compared to firms with information about innovation activities Source: Calculations formulated by this study, based on LIAB data 
Table A.2 Minimum, maximum and percentiles for innovative performance

\begin{tabular}{llllllll}
\hline Min & $5 \%$ & $10 \%$ & $25 \%$ & $50 \%$ & $75 \%$ & $90 \%$ & $95 \%$ \\
0 & 0 & 1 & 2 & 5 & 10 & 20 & 30 \\
\hline
\end{tabular}

Notes: Pooled results for the years 1999/2000 and 2002/2003. Innovative performance as measured by the percentage share of turnover achieved based on new products and services. Source: Elaborated for this study based on LIAB data

Table A.3 Results of wage regression to determine dominance regime

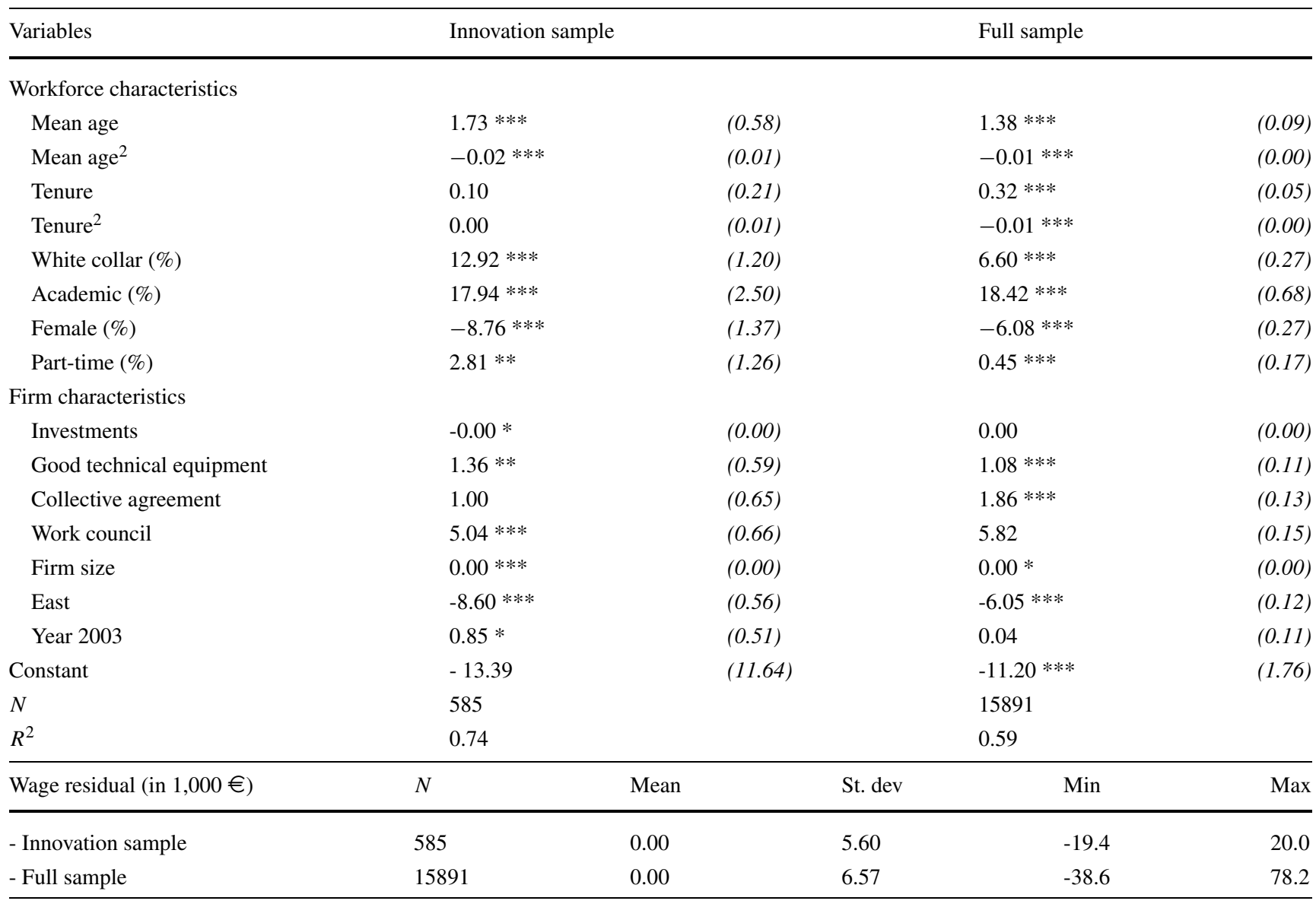

Notes: Pooled results for the years 2000 and 2003. Controls for sector of firms included (results not reported). Dependent variable: Average yearly per-worker salary in each establishment (in 1,000€). Source: Elaborated for this study based on LIAB data

Significance levels $* 10 \%, * * 5 \%, * * * 1 \%$ based on robust standard errors (in italics)

Table A.4 Strategic staffing patterns in full sample

\begin{tabular}{|c|c|c|c|c|c|}
\hline \multirow[t]{2}{*}{ Staffing pattern (\% yes) } & \multicolumn{2}{|c|}{ Full sample } & \multicolumn{2}{|c|}{ Innovation sample } & \multirow[t]{2}{*}{ Difference? } \\
\hline & $\%$ yes & $N$ & $\%$ yes & $N$ & \\
\hline Rejuvenation-inflow of younger & 49.8 & 9330 & 56.4 & 440 & $p=0.007 * * *$ \\
\hline Rejuvenation-outflow of older & 50.0 & 8445 & 54.6 & 434 & $p=0.060 * *$ \\
\hline Loss of firm-specific experience & 67.7 & 9203 & 68.8 & 455 & $p=0.625$ \\
\hline High churning level & 50.5 & 11,412 & 62.3 & 493 & $p=0.702$ \\
\hline Increasing age-heterogeneity & 54.6 & 14,135 & 53.8 & 530 & $p=0.000 * * *$ \\
\hline
\end{tabular}

Notes: Pooled results for the years 1998/1999 and 2001/2002. Prevalence of staffing patterns as indicated by values above (= yes) the median of the respective of all establishments operating in the same industry, by dominance and growth regimes. The $p$-values indicate whether the share of firms experiencing a staffing pattern differs between the full sample $(N=15,891)$ and the innovation sample $(N=585)$. Source: Elaborated for this study based on LIAB data 
Table A.5 Potential confounding factors with respect to staffing patterns

\begin{tabular}{|c|c|c|c|c|c|c|c|}
\hline & $\begin{array}{l}\text { Rejuvenation } \\
- \text { inflow of } \\
\text { younger }= \\
\text { yes }\end{array}$ & $\begin{array}{l}\text { Rejuvenation } \\
\text { - inflow of } \\
\text { older = yes }\end{array}$ & $\begin{array}{l}\text { Loss of } \\
\text { firm-specific } \\
\text { experience = } \\
\text { yes }\end{array}$ & $\begin{array}{l}\text { High churning } \\
\text { level = yes }\end{array}$ & $\begin{array}{l}\text { Growth in } \\
\text { age- } \\
\text { heterogeneity } \\
=\text { yes }\end{array}$ & $\begin{array}{l}\text { Growth } \\
=\text { yes }\end{array}$ & $\begin{array}{l}\text { Dominance } \\
=\text { yes }\end{array}$ \\
\hline Establishment size & + & + & o & o & o & - & o \\
\hline Location in former Eastern part & o & o & - & - & o & + & o \\
\hline Condition of technological equipment & o & o & o & o & o & + & o \\
\hline Per-worker investments for expansion & o & o & o & o & o & o & o \\
\hline Workforce mean age & + & + & - & o & o & - & o \\
\hline Workforce mean tenure & + & + & o & o & - & - & o \\
\hline Workforce age-heterogeneity & o & o & + & o & + & o & - \\
\hline Share of academic workers & + & o & o & o & o & o & o \\
\hline Share of female workers & o & o & o & o & o & o & o \\
\hline Share of part-time workers & o & o & o & o & o & o & o \\
\hline
\end{tabular}

Notes: Pooled results for the years 1998/1999 and 2001/2002, $N=585$ establishments. Confounding factors and staffing patterns computed based on deviations from the median indicator value in the establishments' industry. Relationships between two indicators (significance level at least 10\%): (+) positive, (-) negative, o none. Source: Elaborated for this study based on LIAB data

\section{References}

Abowd, J.M., Kramarz, F.: The costs of hiring and separations. Labour Econ. 10, 499-530 (2003)

Adler, P.S., Kwon, S.-W.: Social capital: prospects for a new concept. Acad. Manag. Rev. 27, 17-40 (2002)

Allen, D.G., Griffeth, R.W.: Job performance and turnover: a review and integrative multi-route model. Hum. Resour. Manage. Rev. 4, 525-548 (1999). Price, J.L. (ed.): Special Issue on Employee Turnover

Asplund, R.: The provision and effects of company training: a brief review of the literature. Nord. J. Polit. Econ. 31, 47-73 (2005)

Autor, D.H., Levy, F., Murnane, R.J.: The skill content of recent technological change: an empirical exploration. Q. J. Econ. 118, 1279-1334 (2003)

Becker, G.S.: Investment in human capital: a theoretical analysis. J. Polit. Econ. 70, 9-49 (1962)

Boockmann, B., Hagen, T.: Arbeitsplatzdynamik und befristete Verträge: Empirische Evidenz aus dem IAB-Betriebspanel für Baden-Württemberg. Mitt. Arb.markt- Berufsforsch. 35, 385-396 (2002)

Boockmann, B., Zwick, T.: Betriebliche Determinanten der Beschäftigung älterer Arbeitnehmer. Z. Arbeitsmarktforsch., 1, 53-63 (2004)

Börsch-Supan, A., Weiss, M.: Age and productivity: evidence from the assembly line. MEA discussion paper No. 148-07, Mannheim (2008)

Burgess, S.M., Nickel, S.: Labor turnover in UK manufacturing. Economica 57, 295-317 (1990)

Burgess, S.M., Lane, J., Stevens, D.: The reallocation of labor and the lifecycle of firms. Z. Arbeitsmarkforsch. 62, 885-905 (2000a) (Special Issue)

Burgess, S.M., Lane, J., Stevens, D.: Job flows, worker flows, and churning. J. Labor Econ. 18, 473-502 (2000b)

Cahuc, P., Sevestre, P., Zajdela, H.: Négociations salariales et segmentation du marché du travail. Écon. Prévis. 92, 43-50 (1990)

Criscuolo, C., Haskel, J.E., Slaughter, M.: Global engagement and the innovation activities of firms. Int. J. Ind. Organ. 28(2), 191-202 (2010)
Daniel, K., Heywood, J.S.: The determinants of hiring older workers: UK evidence. Labour Econ. 14, 35-51 (2007)

Datta, D.K., Guthrie, J.P., Wright, P.M.: Human resource management and labor productivity: does industry matter? Acad. Manag. J. 48, 135-145 (2005)

Daveri, F., Maliranta, M.: Age, seniority and labor costs: lessons from the Finnish IT revolution. Econ. Policy 22, 117-175 (2007)

Davis, S.J., Haltiwanger, J.: Gross job flows. In: Ashenfelter, O., Card, D. (eds.) Handbook of Labor Economics vol. 3, pp. 2711 2805. North-Holland, Amsterdam (1999)

De Grip, A., Van Loo, J.: The economics of skills obsolescence: a review. In: De Grip, A., Van Loo, J., Mayhew, K. (eds.) The Economics of Skills Obsolescence-Theoretical Innovations and Empirical Applications. Research in Labor Economics, vol. 21, pp. 1-26. JAI Press, Amsterdam (2002)

Doeringer, P.B., Piore, M.J.: Internal Labor Markets and Manpower Adjustment. Heath, Lexington (1971)

Düzgün, I.: Alter, Erfolg und Innovation in Arbeitsgruppen - Eine empirische Untersuchung in der Fließbandproduktion. Eul Verlag, Lohmar (2008)

Gabbay, S.M., Zuckerman, E.W.: Social capital and opportunity in corporate R\&D: The Contingent Effect of Contact Density on Mobility Expectations. Soc. Sci. Res. 27, 189-217 (1998)

Göbel, C., Zwick, T.: Age and productivity-evidence from linked employer employee data. ZEW discussion paper No. 09-020, Mannheim (2009)

Guest, R.: Can OECD countries afford demographic change? Aust. Econ. Rev. 40, 149-164 (2007)

Hamermesh, D.S., Hassink, W.H.J., Van Ours, J.C.: Job turnover and labor turnover: a taxonomy of employment dynamics. Ann. écon. Stat. 41/42, 21-40 (1996)

Huergo, E., Jaumandreu, J.: Firms' age, process innovation and productivity growth. Int. J. Ind. Organ. 22, 541-559 (2004)

Huselid, M.A.: The impact of human resource management practices on turnover, productivity, and corporate financial firm performance. Acad. Manag. J. 38, 635-672 (1995)

Hutchens, R.: Delayed payment contracts and a firm's propensity to hire older workers. J. Labor Econ. 4, 439-457 (1986)

Ilmakunnas, P., Maliranta, M.: Aging, labor turnover and firm performance. Helsinki center of economic research discussion paper No. 164 (2007) 
Ilmarinen, J.: Towards a longer work life! Ageing and the Quality of Work Life in the European Union. Jyväskylä, Gummerus (2006)

Jacobebbinghaus, P.: LIAB-Datenhandbuch, Version 3.0. FDZ Datenreport 03/2008, Nürnberg (2008)

Jovanovic, B.: Job matching and the theory of turnover. J. Polit. Econ. 87, 972-990 (1979)

Kanfer, R., Ackerman, P.: Individual differences in work motivation: further explanations of a trait framework. Appl. Psychol. 49, 470482 (2000)

Kanfer, R., Ackerman, P.: Aging, adult development and work motivation. Acad. Manag. Rev. 29, 440-458 (2004)

Koch, M.J., McGrath, R.: Improving labor productivity: human resource management policies do matter. Strateg. Manag. J. 17, 335-354 (1996)

Léné, A.: Enterprise-related training and poaching externalities. In: 14th European Association of Labor Economists Conference, 1922 September 2002, Université Paris 1 Panthéon-Sorbonne, Paris (2002)

Leuven, E., Oosterbeek, H.: The demand and supply of work-related training: evidence from four countries. Res. Labor Econ. 18, 303330 (1999)

Maliranta, M., Mohnen, P., Rouvinen, P.: Is inter-firm labor mobility a channel of knowledge spillovers? Evidence from a linked employer-employee panel. Ind. Corp. Change 18(6), 1161-1191 (2009)

Malmberg, B., Lindh, T., Halvarsson, M.: Productivity consequences of workforce aging: stagnation or Horndal effect? Popul. Dev. Rev. 34, 238-256 (2008)

McGahan, A.M., Silverman, B.S.: How does innovative activity change as industries mature? Int. J. Ind. Organ. 19, 1141-1160 (2001)

Meyer, J.: Does social software support service innovations? Int. J. Econ. Bus. 17(3), 289-311 (2010)

Miller, E.: Strategic staffing. In: Fombrun, C.J., Tichy, N.M., Devanna, M.A. (eds.) Strategic Human Resources Management, pp. 57-68. Wiley, New York (1984)

OECD: Education at a Glance. Organization of Economic Cooperation and Development, Paris (2007)

Prskawetz, A., Fent, T.: Workforce aging and the substitution of labor: the role of supply and demand of labor in Austria. Metroeconomica 58, 95-126 (2007)

Reese, H.W., Lee, L.-J., Cohen, S.H., Puckett, J.M.: Effects of intellectual variables, age, and gender on divergent thinking in adulthood. Int. J. Behav. Dev. 25, 491-500 (2001)

Schaie, K.W.: Rigidity-flexibility and intelligence: a cross-sectional study of the adult life span from 20 to 70 years. Psychol. Monogr. 72, 9 (1958) whole number

Skirbekk, V.: Age and individual productivity: a literature survey. In: Feichtinger, G. (ed.) Vienna Yearbook of Population Research, pp. 133-153. Austrian Academy of Sciences Press, Vienna (2004)

Skirbekk, V.: Age and productivity potential: a new approach based on ability levels and industry-wide task demand. In: Pskawetz, A., Bloom, D.E., Lutz, W. (eds.) Population Aging, Human Capital Accumulation, and Productivity Growth. A Supplement to Population and Development Review, vol. 34 Population Council, New York (2008)

Sonnenfeld, J.A., Peiperl, M.A.: Staffing policy as a strategic response: a typology of career systems. Acad. Manag. Rev. 13, 588-600 (1988)

Staw, B.M.: The consequences of turnover. J. Occup. Behav. 1, $253-$ 273 (1980)

Strotmann, H., Mathes, A.: Innovationstätigkeit, Innovationshemmnisse und Investitionsfinanzierung Baden-Württembergischer Betriebe Ergebnisse der Auswertung des IAB-Betriebspanels BadenWürttemberg 2004. IAW-Kurzbericht 4/2005, Bremen (2005)
Sturman, M.C.: Searching for the inverted u-shaped relationship between time and performance: meta-analyses of the experience/performance, tenure/performance, and age/performance relationships. J. Manage. 29, 609-640 (2003)

Vandenbussche, J., Aghion, P., Meghir, C.: Growth, distance to frontier and composition of human capital. J. Econ. Growth 11, 97-127 (2006)

Veen, S., Backes-Gellner, U.: Betriebliche Altersstrukturen und Produktivitätseffekte. In: Altern, Arbeit und Betrieb. Wissenschaftliche Verlagsgesellschaft, Stuttgart (2009)

Verworn, B., Hipp, C.: Does the aging workforce hamper the innovativeness of firms? (No) evidence from Germany. Int. J. Hum. Resour. Dev. Manage. 9, 180-197 (2009)

Wagner, J.: International firm activities and innovation: evidence from knowledge production functions for german firms. ICFAI J. Knowl. Manag. 6, 47-62 (2008)

Wagner, J.: The research potential of new types of enterprise data based on surveys from official statistics in Germany. J. Appl. Soc. Sci. Stud. 130, 133-142 (2010)

Warr, P.: In what circumstances does job performance vary with age? Eur. Work Organ. Psychol. 3, 237-249 (1993)

Zhou, H., Dekker, R.: The impact of labor relations on innovative output: an exploration of firm-level data in the Netherlands. In: Hakim, L., Chen, J. (eds.) Handbook of Research on Innovation Systems for Business: Technologies and Applications, Hershey, IGI Global, pp. 150-160 (2010)

Katharina Frosch Studium der Wirtschaftswissenschaften an der Universität Hohenheim und an der Universidad Alcalá de Henares (Spanien). Von 2005 bis 2008 wissenschaftliche Projektmitarbeiterin am Rostocker Zentrum zur Erforschung des Demografischen Wandels. MaxnetAging Promotionsstipendiatin am Max Planck Institut für Demografische Forschung. Seit 2009 Lehrbeauftragte an der Munich School of Management. 2010 Promotion zum Thema The innovative capacity of an aging workforce. Seit 2010 freiberuflich tatig in Forschung und Projektentwicklung mit den Themenschwerpunkten Innovation und Entrepreneurship im Bereich Umwelttechnologie und nachhaltiges Wirtschaften.

Forschungsfelder: Innovations- und Personalökonomik, Clean Technology Innovation.

Christian Göbel Studium der Volkswirtschaftslehre an der Universität Mannheim und an der Université Catholique de Louvain (Belgien). Von 2001 bis 2006 Forschungs- und Lehrassistent an der Université Catholique de Louvain und Promotion (2007). Seit November 2006 Wissenschaftler am Zentrum für Europäische Wirtschaftsforschung (ZEW) in Mannheim. Mitarbeit im Forschungsbereich Arbeitsmärkte, Personalmanagement und Soziale Sicherung. Forschungsschwerpunkte liegen im Bereich der "Institutionen der sozialen Sicherung" und beim "Personalmanagement".

Forschungsfelder: Personalökonomik, Empirische Arbeitsmarktforschung, Politikevaluierung.

Thomas Zwick Studium der Volkswirtschaftslehre an der Universität Regensburg und Vanderbilt University (USA), 1993 Abschluss als Diplom-Volkswirt. Von 1994-1998 wissenschaftlicher Mitarbeiter an der Universität Maastricht und 1998 Promotion. 2006 Habilitation an der Universität Zürich. 1998-2008 wissenschaftlicher Mitarbeiter am Zentrum für Europäischen Wirtschaftsforschung (ZEW) Mannheim, seit 2008 Professur für Human Resource Management an der Ludwig Maximilians Universität (LMU) München und ständiger Gastprofessor am ZEW.

Forschungsfelder: Personalmanagement, empirische Arbeitsmarktforschung, Bildung und Weiterbildung sowie industrielle Beziehungen. 